\title{
CHEMISTRY TEACHING AS ENVIRONMENTAL EDUCATION INSTRUMENT IN A HIGH SCHOOL
}

\author{
José Carlos Oliveira Santos*, Joabi Faustino Ferreira, Samara Silva Santos, Isakeline Ferreira \\ Oliveira, Eloíse Nascimento Diniz, Luís Fernandes Francelino Barros, José Adriano Pereira \\ Souza, Adrielly Castro Silva, Irene Maria Lima Cruz and Lays Liliane Silva Araújo Fonsêca
}

\author{
Chemistry Pedagogical Residence Program, Laboratory of Environmental Chemistry and Biofuels, Academic \\ Department of Biology and Chemistry, Federal University of Campina Grande, Brazil
}

\section{ARTICLE INFO}

\section{Article History:}

Received $06^{\text {th }}$ March, 2021

Received in revised form

$14^{\text {th }}$ April, 2021

Accepted $26^{\text {th }}$ May, 2021

Published online $30^{\text {th }}$ June, 2021

Key Words:

Environmental education, Science education, Chemistry teaching, Environment.

*Corresponding author: José Carlos Oliveira Santos

\begin{abstract}
Chemistry Education as an instrument of environmental awareness aims to work on the importance of caring for the environment, seeking a better understanding and development of critical citizen thinking about the environmental problems that are getting worse every day. In this sense, it is necessary to approach environmental education at school, aiming to raise students' awareness. The study of environmental education in schools makes future generations develop more conscious, critical and sustainable thinking in relation to the paths taken that involve the environment and society in general. Thus, this work aims to present the importance of environmental education in the student's daily life and in the school environment, seeking to transmit how it can be an instrument for environmental awareness. In order to achieve the objective presented, it was necessary to develop some activities carried out in the classroom and outside of it, with a second-grade class from the State Elementary and High School located in the Nova Floresta city, Brazil. These activities were divided into five moments, which aimed to analyze knowledge about the generator theme: construction of concept maps in the classroom; preparation of pamphlets, addressing the correct way to dispose of garbage; field class at the city dump and requested a textual production activity; production of parodies, cartoons, comics and cordel; workshop for the production of objects with recyclable materials. According to the results obtained, it was observed the interest and commitment of the students to develop the activities and dedication on the theme, considering that, there was enthusiasm on the part of the students to carry out a certain deepening about the damages to the environment, as well as, the reuse of materials that alleviate the excess of accumulated garbage.
\end{abstract}

Copyright $@$ ( 2021, Karine C. Schmidt et al. This is an open access article distributed under the Creative Commons Attribution License, which permits unrestricted use, distribution, and reproduction in any medium, provided the original work is properly cited.

Citation: José Carlos Oliveira Santos, Joabi Faustino Ferreira, Samara Silva Santos, Isakeline Ferreira Oliveira, Eloíse Nascimento Diniz, Luís Fernandes Francelino Barros, José Adriano Pereira Souza, Adrielly Castro Silva, Irene Maria Lima Cruz and Lays Liliane Silva Araújo Fonsêca, 2021. "Chemistry teaching as environmental education instrument in a high school", International Journal of Development Research, $11,(06), 47987-47992$.

\section{INTRODUCTION}

Environmental education aims to work on the importance of caring for the environment, seeking a better understanding and development of critical citizen thinking about the environmental problems that are getting worse every day (Santos et al., 2016). Based on this, one of the causes for this aggravation is the exaggerated consumerism of people that has been driving a compulsive imbalance in buying more and more diversities of products that are being launched. Consumerism aims to satisfy people's desires, and to circulate products that, in many cases unnecessary, simply because of the desire to obtain more and more goods, leading to financial losses and risks to the environment, caused by the excessive disposal of products which are exchanged for new ones, generated by consumerism and the incorrect disposal of these materials, causing accumulation of waste, often in inappropriate places and in a totally wrong way, contaminating the soil, groundwater, rivers, lakes, among others (Costa and Santos, 2019). Based on this, it is necessary to approach environmental education at school, thus aiming to raise students' awareness, since they are consumers of goods such as cell phones, notebooks, sandals, clothes, accessories and many other things. Currently, the school community is increasingly seeking to work with educational themes focused on the environment, with the aim of making students aware of the importance of working on these themes directed to their daily lives and which can serve as a subsidy to alleviate these problems that come developing within society. For Esteves et al. (2010), environmental education is a comprehensive form of education, through a participatory pedagogical process that seeks to instill in the student a critical awareness of environmental problems. It is important to think and talk about environmental issues 
and there is no better place to do this than in schools. The study of environmental education in schools makes future generations develop more conscious, critical and sustainable thinking in relation to the paths taken that involve the environment and society in general (Santos and Santos, 2020; Araújo and Santos, 2020). According to Penteado (2010) the school is, without a doubt, the ideal place to promote this process. School subjects are the didactic resources through which the scientific knowledge that society already has are made available to students. Based on the author's idea, it is noted the importance of working on this topic with students, through a pedagogical intervention in order to facilitate the approach of the problem and to seek means that facilitate the understanding of the students. This intervention took place through the Pedagogical Chemistry Residency Program, which aims to improve students in undergraduate courses, interconnecting the field of practice and theory using the school environment.

For a long time, environmental issues have taken an extremely relevant path and this was triggered by the predatory way of life adopted by many societies worldwide that contributed to the elevation of environmental impacts, thus making the quality of life of the population was limited. Thus, it is confirmed that the environment has become problematic, because the individual and social impacts and discomfort intensified, arising from the relationship between society and the environment (Lima, 2011). With the environmental changes, it was necessary to look for ways to minimize and make people aware of the risk that environmental impacts can cause to the environment. According to Cruz et al. (2016), the first movements that announced a concern for the environment began to take over the world from the 50's onwards. From that period on, a series of events and manifestations collaborated to disseminate the theme, starting with the foundation from International Union for the Conservation of Nature in Switzerland in 1947. In Brazil, the implementation of Environmental Education at school is indicated by divergent opinions and actions that reproduce several questions. Generally speaking, the critical approach has been presented as an alternative to biologizing, disciplinary, moralistic and immediate forms, in addition to others, which deal with the environmental dimension of educational processes (Tozoni-Reis, 2012).

Environmental issues are gaining a more critical, worrying and investigative look within the school. When environmental issues are discussed in the classroom, they generate reflections and, consequently, to think about the need to work with multicultural concepts that involve the whole community and that are also interdisciplinary. According to Tozoni-Reis (2012), the insertion of environmental education in schools in Brazil is marked by different conceptions and practices that give different approaches. In general, the critical approach has been presented as an alternative to biologizing, disciplinary, moralistic and immediate forms, in addition to others, which deal with the environmental dimension of educational processes. It is important that Environmental Education be included in the school curriculum not for the creation of a new discipline, but that it be part of the curriculum bringing activities to be developed interdisciplinarily (Santos et al., 2016). Even so, this implantation by the curricula is a complicated task. According to Tozoni-Reis (2012), it can be concluded that the resistance of environmental educators to think about the curricular insertion of Environmental Education at school has hindered their more consistent insertion and, on the other hand, it has hindered the contribution of Environmental Education to the organization of richer and more dynamic curricula in the organization of school content. Curriculum insertion does not mean the creation of a specific discipline, but the participation of Environmental Education as the core activity of the curriculum, which brings us to the role of teachers (Silva et al., 2020). As education is a mediating action in the procedure of modifying the lives of all people, it is impossible not to allow Environmental Education to be part of the school curriculum, and it must be operationalized on didactic principles, since the sustainable development of our planet is in the interest of all, without discrimination of social class, culture or race (Bueno and Arruda, 2013).
In addition to the implementation of Environmental Education in the school curriculum, teachers must be prepared for changes so that they can play their role of mediator in the best possible way. It is necessary to invest in the training of these professionals so that they qualify and manage to develop interdisciplinary projects in the school regarding the environment and, with that, make the students develop a more critical and concerned with environmental issues and so that they are prepared for live in modern society. Thus, the school may become a space that generates a new mentality in the relationship between human beings and the natural environment; it can contribute to the construction of environmental citizenship, because when working on problems and possible solutions, everyone will have opportunities to reflect on their reality, proposing a balanced environment and, consequently, a better quality of life for all. The approximation of the students with the knowledge related to the environmental problems of the planet is important and the role of the teacher is to make that knowledge reach his students. For this, you need to be well informed, to know contextualized pedagogical practices, instruments for effective work, to apply diversified methodologies and to be always up to date (Bueno and Arruda, 2013; Dantas et al., 2019). The importance on the topic of Environmental Education discussing with students in public schools has become a necessary educational axis and mediator of other forms of knowledge, since it aims to raise awareness among students, as well as other family groups, through reports, practices and experiences in extraclassroom activities contextualizing teaching and promoting in students another paradigm in relation to absorption and world perspectives, since students will analyze and through the teacher's practice visualize with a more critical look when they associate theory and practice (Santos, 2020; Santos, 2021). According to Feitosa et al. (2016), there is a strong connection between the environment and education, which performs a mutual action requiring new knowledge and practices of social relations that permeate issues of environmental empowerment.

Environmental Education, in addition to showing students reflective social practices in which they discuss environmental problems in their city, neighborhood, etc. they can bring benefits not only to the group involved in the action, but also bring knowledge, clarity, dialogue with neighbors and friends about the importance of being concerned with the environmental impacts that human misconduct can cause to the environment. Thus, it is unquestionable that there is a strong relationship between environmental and human issues and it is important to be aware and understand this relationship so that development can occur in a sustainable way. Regarding social sustainability, Borino (2013) argues that social sustainability is one of the aspects of sustainable development. Its premise is to improve the quality of life of the population; equity in the distribution of income and reduction of social differences. It takes place through effective participation and popular organization. Working with Environmental Education in basic education schools can build good results, since it is already necessary to discuss the school relationship with the environment since it shows students that they are more observant, aware of social mechanisms and of environmental interest, for thus making them aware of the harm they can cause with attitudes of not empathizing with the environment and with that they can take more beneficial measures and attitudes both for the population and for their own quality of life. However, Environmental Education does not intend to impose behavioral models on its participants, its intention lies in the construction of a transformative and sensitizing process, in which there is a reflection on the habits and attitudes of citizens. Therefore, it is easy to say that one of its greatest challenges is the creation of mechanisms that really favor the exercise of citizenship (Cruz et al., 2016; Medeiros Filho et al., 2020). There are several ways of working with environmental education in schools; topics related to the environment can be addressed, formally or dynamically, such as problems and possible solutions in general and / or specific problems experienced by students in their daily lives. In this way, students are able to reconcile their daily lives with what they learn at school and their understanding becomes more meaningful. As a result, environmental education becomes a great ally of the school in terms of understanding aspects related to the environment and the 
society in which they live (Silva and Santos, 2019; Santos and Silva, 2019). Thus, the learning process of Environmental Education requires permanent stimuli, where the individual recognizes and better understands the environment of which is part, and through the acquired concepts seek new forms of relationship with the environment, based on the principles of respect and integration environmental (Cruz et al., 2016). The school space itself has the capacity to bring reflections and important themes that are neglected by organs federal, state and municipal bodies, and bringing these types of clarity regarding the external environment we live in makes students see the benefits and changes with respect to its programmed mentality that our actions do not change the environment in which we live. Through the didactics and planning of the teacher, students can be encouraged to participate actively in the entire educational project that the school planned, articulated and united the activities to be done in a collective, harmonious way and looking for new ways to resignify more educational values and actions applied. This makes us consider that the environmental dimension can be configured as a trigger for ethical and humanistic actions, actions that transcend contexts and borders. To act in this way requires overcoming the bonds established by the disciplinary curriculum and the school walls (Mazzarino et al., 2012).

The fundamental role of Environmental Education is undoubtedly the clarity and knowledge that people will have on the subject, how the policies and means responsible for the lack of organization of garbage work, for example, our contribution portion, teaching students about the possible causes and effects that our actions generate in the environment, which are often not dealt with by higher bodies. In this way, the role of the school in the education and awareness of students becomes a means of change that is initially personal and that can be passed on to another person and future generations. See also according to Ozório et al. (2015) that in addition to information and concepts, it is also important that the school works with attitudes and the formation of values with appropriate methodologies and procedures. Environmental education is a topic that is currently being discussed due to the fact that the need to improve the world in which we live is perceived, as it is easily noticed that we are increasingly regressing in our quality of life in general, allowing ourselves to be led by our daily obligations. Our time seems shorter and shorter because we have more and more commitments. According to this thought, today's society with so many distractions, technological advances and the hustle and bustle of everyday life, simple actions to change behaviors and attitudes that generate less impact on the environment become increasingly rare and less important attitudes, thus, informing students in the basic education network about caring for nature is necessary and salutary that such measures to protect and care for the environment are valid (Silva et al., 2016; Santos et al., 2017). In the comprehensive context that educational actions in schools together with teachers and the general school body, the author Guimarães (2005) expresses that in Environmental Education, the educator must work intensively on the integration between human beings and the environment and be aware that human is nature and not just part of it. Based on this perspective, Environmental Education is not to be taken as a discipline of practice and theory only, but in a way that works the student, their integration in nature not as something part of it but part of it, and if not future generations will be compromised due to the environmental impacts of today. The objective of this work is to present the importance of environmental education in the student's daily life and in the school environment, seeking to transmit how it can be an instrument for environmental awareness.

\section{MATERIALS AND METHODS}

In order to achieve the objective of this research, it was necessary to develop some activities carried out in the classroom and outside the school environment, with a second grade class from the State Elementary and High School José Rolderick de Oliveira located in the city of Nova Forest, Paraíba, Brazil. These activities were divided into five moments, which had the purpose of analyzing the knowledge about the generator theme. In the first moment, a conceptual map was carried out in the classroom, seeking to identify the students' previous knowledge on the topic addressed. In the second moment, a pamphlet elaboration activity was carried out, addressing the correct way to dispose of garbage. In the third moment, a field class was held at the city dump and a text production activity was requested. In the fourth moment, a production of parodies, cartoons, comics and cordel was produced. At the end of the activities, in the fifth moment, a workshop for the production of objects with recyclable materials was carried out.

\section{RESULTS AND DISCUSSION}

Starting the discussions on the activities that were developed during the project, it is important to remember that the referred study was carried out at the José Rolderick de Oliveira State School of Elementary and Secondary Education located in the city of Nova Floresta, Brazil, which included 30 students 2nd year of high school, of both sexes. During this study, activities were carried out, in which it was sought to identify the students' previous knowledge and understanding about the topic addressed. Initially, it was discussed in the classroom points that affect environmental education, based on sustainability. The damage caused to the environment in the present day was addressed, thus seeking the students' opinion in the form of a discussion to form points that would justify these students, which is sustainability. With this discussion, a conceptual map was created from the points that were expressed by the students, based on this, the following information was obtained described in Figure 1.

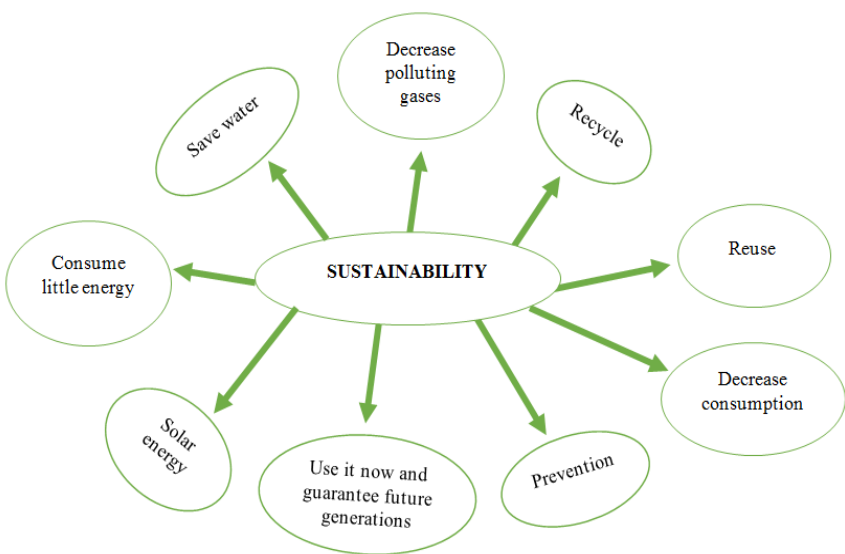

Figure 1. Conceptual map built with the sustainability theme

Based on the knowledge passed on by the students, it can be noted that there is an understanding of them regarding the concept of sustainability, as observed in the conceptual map above. Two points that were widely discussed were reuse and recycle, which, in most cases, end up being confused as if they had the same purpose. In such a way, the difference of each one was approached in the classroom, making connection with the students' daily life, this time, it was explained that reusing is the process of reusing the material in the same function or in other possible applications. As for recycling, it is explained in a way that it can transform a material into something new, in which both have a fundamental role to alleviate environmental problems. Another important point that was addressed and highlighted was consumerism, in which students point out that it is necessary to raise awareness to reduce this consumption, considering that it is something that reflects directly on the environment, due to exaggerated consumption. And among so many other points presented, a certain concern with the future was noted, such as, the students emphasized that one should "use now and guarantee future generations", that is, it is necessary to practice sustainability today, to guarantee a future assured of the damage suffered today. Following the activities, students were asked to make an observation at school to identify the types of garbage present in the school environment. After checking all the environments of the school, a conversation circle was held in the classroom, the purpose of which was to discuss the types of garbage most produced within 
the school and the places where they present the greatest production of dirt. Accordingly, it was found that the greatest accumulation of garbage present in the school occurs in the schoolyard, in which papers and snacks are thrown among others, and specifically in the evening shift, as it is attended by elementary school students, whose maturity is minimal and they are not concerned with the damage that this waste disposal can cause to the environment. Based on what was discussed in the classroom, they were instructed to form groups and create pamphlets for awareness, containing important information about some environmental impacts caused by the incorrect disposal of garbage, and the public chosen to be made aware were these elementary school students from afternoon shift, in order to instruct and inform them about the damage that waste causes to society. About five pamphlets were prepared, with different images and content containing reflective awareness phrases, as shown in Figure 2. In this way, visits were made in the classrooms and delivery of these pamphlets and a brief conversation with the students, guiding them on the correct disposal method and how this action can prevent damage to the environment.

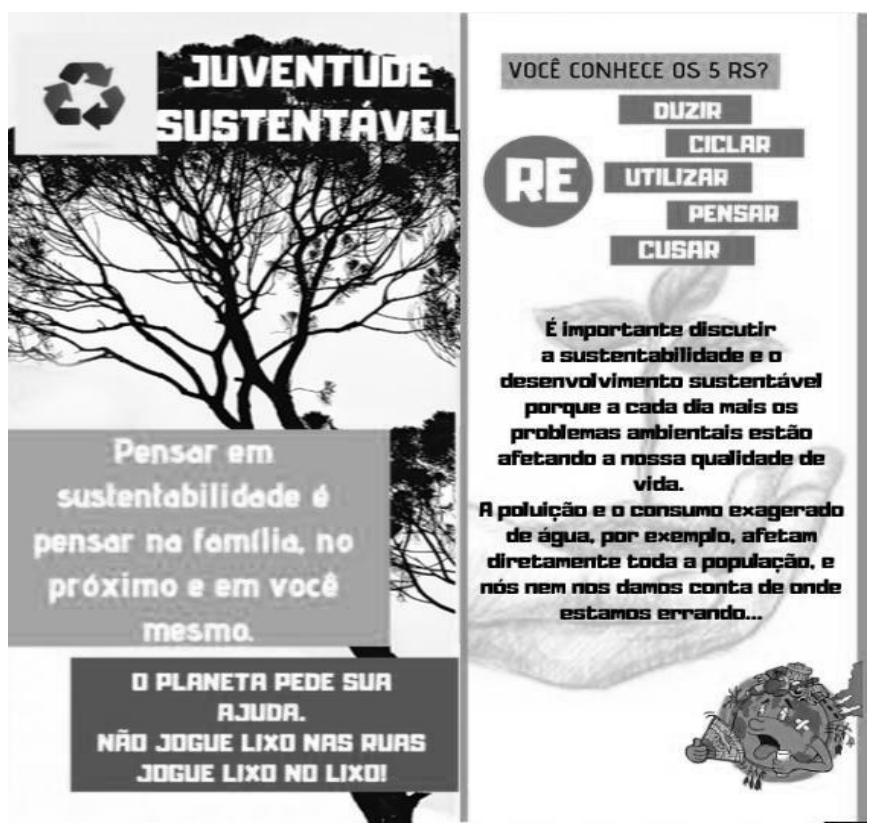

Figure 2. Sustainability pamphlet

At another time, a field class was held, where a visit was made to the city's garbage dump in order to introduce students to the environment in which the entire community is disposed of. At that moment, a discussion was made, presenting the types of garbage found, the risks caused by incorrect disposal, and it was also addressed about the animals present there, which feed on the remains of food that are deposited there. At the same time, a dialogue began with a waste picker who was separating waste and he reported his experiences as a waste picker and emphasized the difficulties he faces when working in this environment, which offers many risks to his health. After that moment, the types of garbage were presented in the form of slides, and during this presentation questions were asked about the types of garbage that the students observed while they were in the municipal garbage dump (Matias et al., 2019). The types of garbage presented were: organic, hospital, green, domestic, commercial, electronic waste, among others. Questions were asked about which type of garbage was most present in the visited environment, and according to what was seen, it was noted that most indicated the discarded garbage as grocery bags, food scraps that attract dogs, birds and insects, as witnessed. Another type of garbage that was widely discussed was electronic waste, given that there were a lot of computer monitors, televisions and appliances in the place, not to mention the accumulation of batteries that were present in the garbage, which have heavy metals that cause the injuries environmental issues. Following up, a video on garbage and pollution was shown, shown on a national television program, which portrays the consequences of garbage and air pollution, whose report ran through some regions of Brazil and India, showing the suffering experienced by residents these regions and health problems caused by the contamination of garbage and metals that contaminate rivers. Concluding this moment, it can be observed that the students showed a lot of understanding about the questions presented during the entire trajectory of discussions held during the classes, showing that it is of utmost importance to work on these themes inside and outside the classroom. At another time, a presentation was made using slides as a didactic resource, exposing about the waste treatments, which sought to pass on to the students details of how these processes are carried out. In this exhibition, open-air dumps, sanitary landfills, selective collection, composting, garbage incineration and special garbage were discussed. It was pointed out that the method that offers the most damage to health and the environment is open-air dumps, which has an accumulation of insects and rats, and unfortunately it is the most used method in the region. The importance of sanitary landfills and their appropriations for receiving solid waste was also highlighted, and that this method is the most common in the world, it was also demonstrated how these landfills work. Selective collection was also presented, how it is made and also which materials are not recycled. Continuing these treatments, we talked about composting, which is a way of treating organic waste, being a low-cost method and easing the organic volume. The incineration method was also introduced, which is mainly used to treat hospital waste, however, it is a high cost process.Finishing the presentations, we also addressed the 5r's, which means: reuse, reduce, rethink, refuse and recycle, which aims to reduce waste, refrain from excessive consumption, transform something used in something new, to reuse materials without use and use for other means and reflect on socioenvironmental methods.

After reviewing all these methods, students were asked to form groups and to produce parodies, cartoons, comics and string, which should contain information about what had already been covered in the classroom and was later presented to the other classmates (Sousa et al., 2015; Santos and Araújo, 2018). The parody emphasized the suffering of the planet over the damage that human beings are causing, by not taking care of the environment, also highlighting in the lyrics of the parody that, there is a certain indignation at the lack of awareness about the damage that the planet has been experiencing. The cartoon (Figure 3 ) shows that many people use social networks to raise awareness about the correct disposal of waste and the harm caused to nature, however, they do not exercise what they post. It can be seen in the image that, when publishing such a message, the character chooses to discard what appears to be a cup with a straw on the floor, instead of throwing it in the trash, considering that the bins are at his side. This illustration depicts a reality in our society.

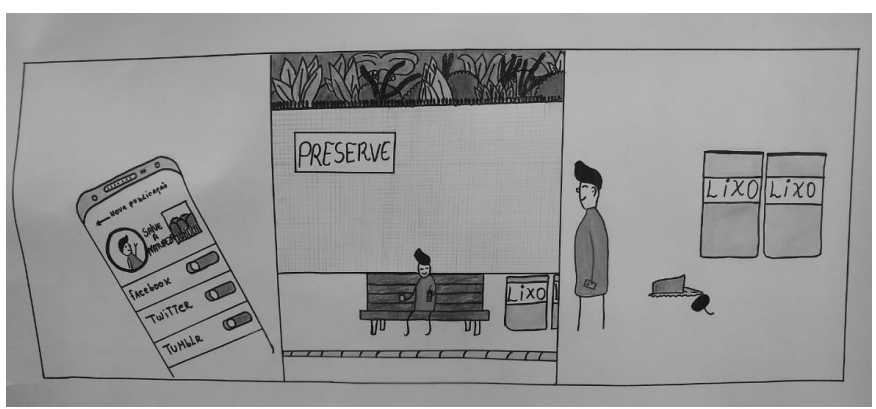

Figura 3. Cartoon "Preserve".

The comic story showed a dialogue between two children, showing the action of a girl scolding the boy, for throwing the bottle on the floor, and the trash can is right next to him. It can be observed that throughout history, it portrays the reality experienced within our society, whose population chooses the easiest way, instead of exercising the fair way of acting and mitigating the accumulation of garbage on the streets. Among the activities developed, the 5r's approach through the cordel stands out, which was a medium chosen to express the problems worked in the classroom, bringing to a better known language in our region. According to everything that has 
already been shown, it can be seen that there are several means of awareness, which can be used in the school environment (Santos et al., 2016). At the end of the activities, a workshop was held with recyclable materials, and at this moment the class was divided into groups for making objects using such materials. In this activity, several types of objects were obtained (Figure 4). Among the productions, organic waste was used to make a brigadeiro, which was used for banana peel as the main ingredient, showing that there are sustainable ways to use organic material. Another object made during the workshop was an airplane using cardboard that is widely discarded in supermarkets, being classified as commercial waste, it is a material that causes a lot of accumulations in the streets in front of the shops, and could be recyclable or reused for the manufacture of so many other materials.

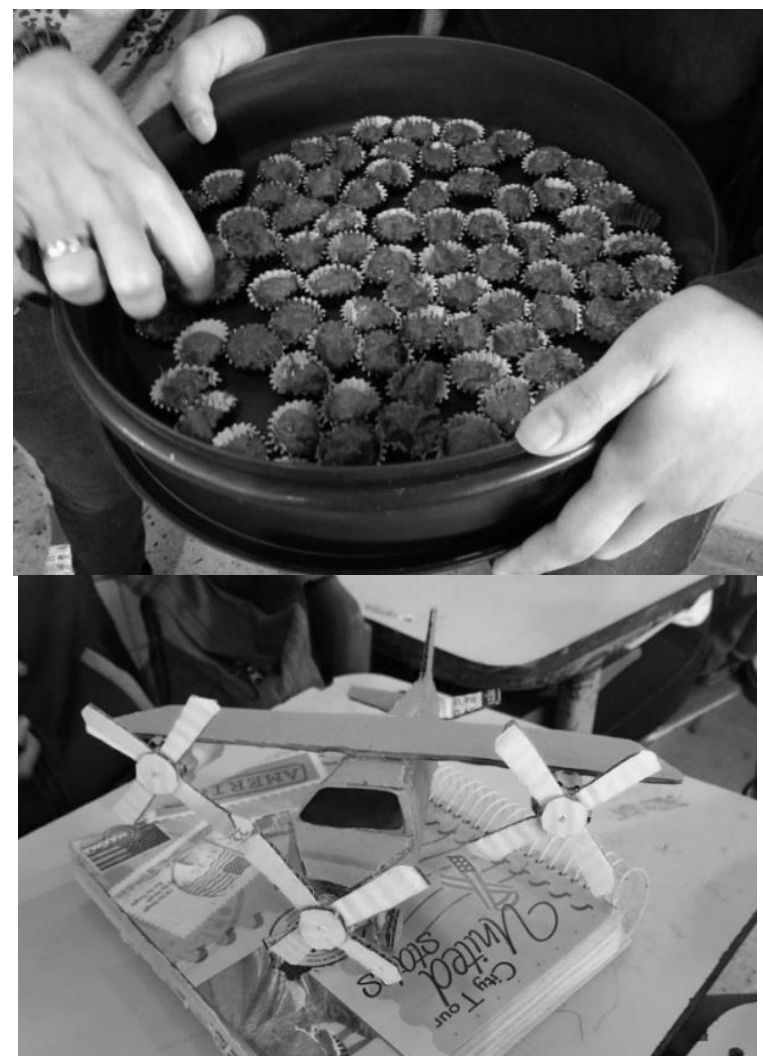

Figure 4. Objects produced using garbage

Therefore, in general, a very satisfactory result can be obtained, through all the activities carried out during the research period, as well as the interest and commitment of the students to develop the activities and dedication on the topic, taking into account considering that, there was enthusiasm on the part of the students to carry out a certain deepening about the damages to the environment, as well as, the reuse of materials that alleviate the excess of accumulated garbage (Santos et al., 2021; Viana et al., 2021).

\section{CONCLUSION}

The present work sought to address environmental education in the classroom, having as target audience students from the public school system in the municipality of Nova Floresta, Brazil. In general, it can be observed that the students showed a lot of interest in knowing the damage caused to the planet due to the large accumulation of garbage produced by society. In the midst of the results obtained, it was sought to analyze the performance and understanding of the students during the activities carried out, in which a very satisfactory result was obtained. Therefore, it was understood the importance of working inside and outside the classroom, a problem so present in the daily lives of our students, that most of the time they only come to talk about the damage that the planet is suffering through the media, but not has this opportunity to be working in the classroom.
Acknowledgment: The authors would like to thank the financial support of PRP / CAPES / UFCG.

\section{REFERENCES}

Araújo, J. V. S.; Santos, J. C. O. (2020). Educação em Química: o uso da experimentação no ensino de soluções. In: Monteiro, S. A. A educação em suas dimensões pedagógica, política, social e cultural. v. 2. Ponta Grossa: Atena, p.155-164.

Borino, S. (2013). A Construção de uma Rede Social Alternativa para Tratamento do Câncer. (Dissertação de Mestrado apresentada ao Programa de Pós-Graduação em Desenvolvimento Regional e Meio Ambiente). Centro Universitário de Araraquara UNIARA. Araraquara.

Bueno, R. L.; Arruda, R. A. (2013). Educação Ambiental. Revista Eventos Pedagógicos, 4 (2): 182-190.

Costa, O. F.; Santos, J. C. O. (2019). Alternative Pedagogical Methodologies of Solidarity Economy in Youth and Adult Education. IOSR Journal of Research \& Method in Education, 9 (3): $21-25$.

Cruz, C. A.; Melo, I. B. N.; Marques, S. C. M. (2016). A educação ambiental brasileira: história e adjetivações. Revista brasileira de educação ambiental, 11 (1): 183-195.

Dantas, D. L. S.; Santos, J. C. O.; Maknamara, M. (2019). Contributions of PIBID Biology to Teacher Training at CES/UFCG. Revista de Ensino de Ciências e Matemática, 10 (5): 85-99.

Feitosa, A. K.; Silva, C. M.; Silva, J. L. (2016). Educação Ambiental na percepção de professores em uma escola de ensino fundamental no município de Iguatu, CE. Revista educação Ambiental em Ação, 15 (56): 23-32.

Gil, A. C. (2010). Como elaborar projeto de pesquisa. 5. Ed. p. 27. São Paulo: Atlas.

Guimarães, M. (2005). A dimensão ambiental na educação. Campinas: Papirus.

Lima, G. L. C. (2011). Educação Ambiental no Brasil: Formação, identidades e desafios. 1.ed. Campinas: Papirus.

Marconi, M. A.; Lakatos, E. M. (2010). Metodologia Científica. 7. ed. São Paulo: Atlas, 297p

Matias, R. S.; Santos, F. J. M.; Santos, J. C. O. (2019). Chemistry and environmental education in relevant disposal of batteries. Academia Journal of Scientific Research, 7 (1): 049-052.

Mazzarino, J. M.; Munhoz, A.V.; Keil, J. L. (2012). Currículo, Transversalidade e sentidos em Educação Ambiental. Revista Brasileira de Educação Ambiental, 7 (2): 51-56.

Medeiros Filho, F. C.; Fonseca, L. L. S. A.; Santos, J. C. O. (2020). Combating Aedes aegypti in Brazil: An Interdisciplinary Proposal in Teaching Biotechnology Chemical. Biotechnology Indian Journal, 16 (3): 211-216.

Ozório, M. S.; Filho, M. P. S.; Alves, N.; Job, A. E. (2015).Promovendo a conscientização ambiental: Resultados de uma pesquisa realizada com alunos do ensino médio sobre polímeros, plásticos e processos de reciclagem. Revista brasileira de educação ambiental, 10 (2): 11-24.

Penteado, H. D. (2010). Meio Ambiente e formação de professores. 7 ed. São Paulo: Cortez.

Santos, J. C. O. (2020). Ensino de Química e Educação Ambiental: estudos de caso e relatos de experiência. Rio de Janeiro: ePublicar, 180p.

Santos, J. C. O. (2021). Vivências na Residência Pedagógica em Química. Rio de Janeiro: e-Publicar, 149p.

Santos, J. C. O.; Araújo, V. K. S. (2018). The influence of teacher (des)qualification in teaching chemistry in Brazil. Academia Journal of Educational Research, 6 (2): 030-035.

Santos, J. C. O.; Costa, A. P.; Araújo, A. L.; Martins, J. S. (2016). Chemistry and Sustainable Development: The Use of Brazilian Regional Plants in the Context of Chemical Concepts. Academia Journal of Scientific Research, 4 (9): 276-278.

Santos, J. C. O.; Costa, A. P.; Araujo, A. L.; Martins, J. S.; Oliveira, L. F. B.; Lima, V. C.; Oliveira, R. J.; Dantas, D. L.; Melo, F. M. A. (2017). The Juazeiro (Ziziphus Joazeiro Mart.) and the 
Formation of Concepts and Parameters in Chemical Technology Education. Asian Journal of Applied Sciences, 5 (2): 137-141.

Santos, J. C. O.; Costa, E. O.; Lima, R. C. S. (2021).Chemistry and environmental education: extraction of natural extracts from the Brazilian semiarid. International Journal of Development Research, 11 (3): 44900-44903.

Santos, J. C. O.; Costa, E. O.; Lima, R. C. S. L.; Araújo, D. S.; Sousa, A. S. (2016). Alternative ways in chemistry teaching: providing the creativity of high school students. Academia Journal of Educational Research, 4 (4): 069-074.

Santos, J. C. O.; Oliveira, L. F. B.; Lima, V. C.; Melo, F. M. A. (2016). Chemistry of Cosmetics: Using Contextualization and Interdisciplinarity as allowance for Chemistry Teaching. Academia Journal of Educational Research, 4 (11): 171-174.

Santos, J. C. O.; Santos, E. P. (2020). Use of Medicinal Plants of Brazilian Caatinga in a Perspective of Solidarity Economy. International Journal of Environmental \& Agriculture Research, 6 (7): 36-42.

Santos, J. C. O.; Silva, R. J. D. (2019). Educational Games Applied to Chemistry Teaching. In: Jayakumar, R. Research Trends in Multidisciplinary Research. v. 9. New Delhi: AkiNik Publications, p.15-31.
Silva, A. C.; Souza, J. A. P.; Fonseca, L. L. S. A.; Santos, J. C. O. (2020). Utilização de aulas experimentais no ensino médio: estudo das soluções. In: Freitas, P. G.; Mello, R. G. Estudos, pesquisas e práticas em ciências da saúde. v. 3. Rio de Janeiro: e-Publicar, p.115-127.

Silva, A. S.; Silva, R. J. D.; Oliveira Junior, J. C.; Santos, J. C. O. (2016). An Experimental Approach to Chemistry Teaching: Oxygenated Organic Function Identification Tests on Cosmetics. Academia Journal of Scientific Research, 4 (3): 069-074.

Silva, R. J. D.; Santos, J. C. O. (2019). Chemical educational game: A tool for understanding Organic Chemistry. Academia Journal of Educational Research, 7 (7): 235-241.

Sousa, A. S.; Silva, A. S.; Araújo, D. S.; Silva, R. J. D.; Costa, E. O.; Lima, R. C. S.; Oliveira Junior, J. C.; Paula, J. C. F.; Santos, J. C. O. (2015). O Pibid contextualizando o ensino de química através do teatro. Química: ciência, tecnologia e sociedade, 4 (2):71-80.

Tozoni-Reis, M. F. C. (2012). Educação Ambiental na escola básica: reflexões sobre a prática dos professores. Revista Contemporânea de Educação, 7 (14): 12-19.

Viana, M. R. S.; Santos, J. C. O.; Fonseca, L. L. S. A. (2021). Study of pesticides in the environmental chemical education. International Journal of Development Research, 11 (3): 4534545348 . 